\title{
A transaction cost approach to assess the Water Framework Directive implementation
}

\author{
M. Laurenceau, F. Destandau \& A. Rozan \\ UMR Cemagref-ENGEES Gestion des Services Publics, France
}

\begin{abstract}
To assess integrated water policy performance, pollution abatement costs shall be weighted against overall policy implementation costs. The European Water Framework Directive (WFD) requires the design of cost-effective programs of measures (pollution abatement costs). Other policy implementation costs are difficult to identify and measure. We propose a transaction cost approach to balance the costs of programs of measures with overall costs or constraints related to the implementation process. We provide examples from France, Belgium and The Netherlands to illustrate transactions characteristics and transaction cost optimisation strategies. The factors affecting transactions constitute key elements for policy change.
\end{abstract}

Keywords: transaction costs, policy, programs of measures, cost-benefit analysis.

\section{Introduction: a transaction cost framework to assess policy}

From an economic perspective, government failures have been addressed relatively recently by Public Choice economists (i.e. the State is not a "benevolent, omniscient, and omnipotent" planner [1]), political economists and neo-institutional economics. Their assessment was given little attention and thus implies limited explanatory power. Public intervention has its own constraints, and can result in significant indirect costs either for the regulator itself (i.e. administrative and transaction costs [2-4]), for regulated agents (i.e. transaction costs [5]), or for society (i.e. social marginal costs of public funds [6]). Jobin [7] recalls that governance of a large number of public transactions is subject to one or more of three hazards: cost excesses, bilateral dependency, and probity. 
In light of these findings, the concept of transaction cost and its predictive capacity offers an interesting framework to assess the effects of constraints inherent to public intervention. The approach is not fatalistic. As highlighted by Dixit (cited in [7]) policy outcomes are hereby considered as the results of various transactions costs and the strategies of participants to cope with these costs. In other words, transaction costs are used to explain governance structures. Neo-institutional economics regards institutions at the centre of the analysis, as they affect the costs of running the economic system (or transaction costs) and its performance [8]. We need governance structures that keep transaction costs low and thereby optimize performance.

Transaction cost theory has been mostly applied to private organisations and contractual relationships but the public sector remains an interesting investigation field. Dixit (cited in [7]) mentions that "information impactedness, opportunism, asset specificity" (the more specific the transaction - in terms of site, physical, human, dedicated, brand-name capital, temporal/spatial aspects the greater the transaction costs) are the main transaction costs relevant to the public sector. McCann and other authors [3, 4] quantitatively assessed administration costs of (agri-)environmental policies implementation in the U.S. They highlighted the importance of balancing these costs with pollution abatement costs. Jobin [7] is perhaps the one of the few to have explicitly reported the practical application and usefulness of transaction costs theory to the public sector.

The potential of using transaction cost theory for policy assessment obviously faces important challenges such as the definition of a public transaction or limits in defining transaction costs. Given other existing policy assessment methods focusing mostly on impact assessment evaluation, a transaction cost framework offers the opportunity to link up governance structures, a process and performance. We can distinguish between two main approaches to operationalise the transaction cost theory. Some authors conducted a direct quantitative assessment of policy implementation transaction costs, which implies a categorization of transaction costs (see transaction costs typology in annex). Other authors recognize the difficulty to define and measure transaction costs and thus use the critical dimensions of transactions as proxies (i.e. Ménard and Saussier [9]). Both approaches can be relevant decision support tools. The next section will focus on the Water Framework Directive (WFD) implementation and the identification of a relevant transaction to analyse.

\section{The WFD implementation: focus on cost-effectiveness and cost-benefit analysis}

As highlighted by Brouwer [10], the WFD is interpreted as an ecological directive (see Kaika and Page [11] for details on the role of political actors for decision-making on the environmental objective). It indeed sets an ambitious target of "good ecological status or potential" for water bodies that Member 
States have to achieve. Meanwhile, the WFD recognizes the role of economics in reaching environmental water quality objectives (i.e. articles 5 and 9) which makes it an original, new and complex process. Among other economic criteria (i.e. cost recovery) required to implement the Directive, cost-effectiveness has a direct impact on the environmental target achievement. It supports the justification of measures to be taken and cost disproportion assessment. Combining ecological and economic objectives is not obvious. According to Brouwer, economic efficiency criteria are kept outside the decision-making procedure so as not to mix up ecological and economic principles. At the same time, the economic analysis under the responsibility of Member States' public authorities is known to be a subjective and political exercise (i.e. CIS [12]).

Considering the cost-effectiveness of programs of measures as a crucial issue in reaching the environmental objectives, we will investigate this process from a transaction costs perspective. Indeed, transaction costs are also considered as an important parameter for water policy: Brouwer mentions that "administration, monitoring and other transaction costs are in most cases not included in costs estimation" (resulting in higher ex post than ex ante costs of public investment decisions). We thus suggest balancing costs of programs of measures with indirect (transaction) costs related to the elaboration process. The underlying objective is to assess whether undertaking a social cost benefit analysis (CBA) meant to achieve environmental objectives at lower costs actually optimizes transaction costs.

The CBA carried out under the WFD is qualified as social CBA. The social CBA takes into account social costs and benefits that are not encompassed by the regular market mechanisms [13]. The spirit is to optimize environmental benefits from reaching the good status/potential while minimizing costs of measures to achieve the good status/potential. This raises the question of allocation of costs and benefits. In the process, public authorities need to look for winners and losers and thus decide upon issues such as stakeholders' capacity to pay for measures (affordability), including public authorities, financial aspects (i.e. potential transfers). One can understand the importance of the types of measures selected, communication and negotiations over measures selection and associated costs.

A main question is: what does the CBA actually assess? This is most likely different from a country to another. It is why this paper aims at bringing a framework to assess the process of developing cost-effective programs of measures with a transaction cost approach. Sections 3 and 4 will provide illustrations from different neighbouring Member States: France, Belgium, and The Netherlands. A transaction costs approach puts attention on the institutional context that sets the rules of the game (the steps that need to be performed) as well as the governance structures with related costs and competencies (how the steps are performed). The idea of comparing several institutional contexts is to get a first understanding of transaction cost optimization strategies of different governance structures. 


\section{The social CBA under the WFD}

\subsection{Tasks}

In order to analyse the organisational arrangements or governance structures involved in performing the CBA, we suggest identifying the different tasks the social CBA is composed of. The focus on the CBA implies that despite their effects on the environmental objectives to be achieved and on the costs of measures, the delimitation (size) and classification (natural, modified, artificial) of water bodies are taken as given.

\subsubsection{Selection of measures and cost-efficiency analysis}

First, the measures considered by river basins to target pressures imply the assessment of potential effects of measures (link pressure-impact) and the costs or measures. In order to assess transaction costs, certain aspects are worthwhile being investigated:

- the number and roles of actors involved

- $\quad$ the time spent (on selecting measures)

- $\quad$ the existence of decision-support tools (i.e. models)

- the methods and methodology used

- $\quad$ the distinction made between basic and supplementary measures

- $\quad$ administrative procedures required to carry out the selection of measures

- the documents/guidance provided

- coordination that was required

- number of studies undertaken/outsourced

- $\quad$ potential staff hired

- number of meetings, discussions, negotiations

\subsubsection{Cost-benefit analysis}

This second step corresponds to balancing the costs of measures required to achieve the ecological objectives with the potential benefits of reaching this target. It implies a set of assumptions, definitions and valuation methods (Bouma [14]) which provides particular boundaries and a specific role to the CBA. At this stage, additional points of attention would be:

- $\quad$ costs and benefits components

- time horizon

- the scale of analysis (national, province, river basin, sub-river basin, water body)

- $\quad$ the frequency of analysis (systematic or only when considered necessary)

\subsubsection{Costs disproportion}

The third and last step under consideration is the assessment of disproportionate costs (solely on the basis of costs of supplementary measures) that can justify economic exemptions to reach the good status/potential. The issue is whether the implementation of the WFD is not economically efficient (even the least cost 
way). It is up to Member States to define what is disproportionate (According to Brouwer, costs disproportionality is not a standard economic concept, it is subjective and depends on political economy and uncertainty regarding definition and measurement scale). One can thus expect more concern for competitiveness than for welfare gain or losses: "mentioning excessive costs is not the same as economic efficiency" [10]. The main points of consideration are similar to the two previous steps, and we may question the allocation of the financial burden (given the possible distribution through existing or future pricing policies).

\subsection{Organisational arrangements}

Analysing organisational arrangements corresponds to identifying significant choices made for the three tasks detailed above in order to assess their effects on transaction costs. The following three tables describe certain aspects of the process and progress regarding the implementation of the tasks (section 3.1) reported by France, Belgium (Flemish region) and The Netherlands. Based on reports and personal communications [15-18], the information provided is depicted in terms of decision-making process, guidance provided, studies undertaken as well as temporal and spatial considerations.

These tables do not present exhaustive information but highlight practices that would inevitably impact transaction costs. It may be added that some countries/river basins districts will ask for economic exemptions and others not (i.e. Flemish region), the later allowing for certain simplifications.

From these tables, it appears that some of the main differences in undertaking the tasks described are the scale of analysis (i.e. a national CBA in the Netherlands and CBA at the water body scale in France) or the timing of the steps taken. For instance, France assesses stakeholders' capacity to pay before a CBA can be justified whereas The Netherlands first carried out a CBA and then investigate costs distribution and affordability issues, which allows for considering transfers.

The scale at which the information is processed is also significant. In Belgium, the two administrative districts (Flemish and Walloon regions) are responsible for designing programs of measures whereas in France, the river basin is the relevant scale. These frontiers between administrative/political and natural boundaries can have an impact on data availability and the scale of action.

Another point to consider when investigating arrangements as a consequence of transaction costs is the outsourcing or integration of tasks. For instance in France, the water agency Rhin-Meuse carried out studies related to exemptions whereas the Rhône Méditerrannée et Corse water agency outsourced to a consultancy.

As it is not possible to assess all costs and benefits in an economic way, countries made choices according to optimize transaction costs within given institutional contexts. 
Table 1: $\quad$ Information reported on selection of measures and CEA.

\begin{tabular}{|c|c|c|}
\hline & & Selection of measures and CEA \\
\hline \multirow{6}{*}{ FR } & $\begin{array}{l}\text { Choice of } \\
\text { measures }\end{array}$ & $\begin{array}{l}\text { From a long list of measures (local scale technical staff), } \\
\text { water agencies' staff establish one short-list with support of } \\
\text { DIREN (regional environmental authority competent on the } \\
\text { river basin) }\end{array}$ \\
\hline & Guidance & $\begin{array}{l}\text { The central level (Ministry in charge of Environment) } \\
\text { provides guidance and general recommendations on the } \\
\text { selection of measures, explanations on CEA (i.e. Excel sheets } \\
\text { for the costs of measures) }\end{array}$ \\
\hline & Method & $\begin{array}{l}\text { Experts judgement or modelling tool (pollutants transfer } \\
\text { model "Pegase"). PIRENE model for the Seine Normandy } \\
\text { river basin. } \\
\text { No real CEA methodology, no CEA outsourced to } \\
\text { consultancies }\end{array}$ \\
\hline & Studies & Some studies on CEA but no general research program \\
\hline & Scale & $\begin{array}{l}\text { Water agencies undertake separately CEA and affordability } \\
\text { assessment, but the ministry asks for the integration of these } \\
2 \text { steps }\end{array}$ \\
\hline & Time & CEA and CBA carried out at a different times \\
\hline \multirow{6}{*}{$\begin{array}{c}\mathrm{BE} \\
\text { Flemish }\end{array}$} & $\begin{array}{l}\text { Choice of } \\
\text { measures }\end{array}$ & $\begin{array}{l}3 \text { scenarios or measure packages (low, intermediate, high } \\
\text { implementation levels of the WFD) }\end{array}$ \\
\hline & Guidance & $\begin{array}{l}\text { Guidelines for drafting sub-basin management plans } \\
\text { Handbooks of other countries (Germany, The Netherlands) } \\
\text { Handbooks resulting from } 2 \text { pilot studies for data collection } \\
\text { methodology }\end{array}$ \\
\hline & Method & $\begin{array}{l}\text { CEA partly quantitative and partly qualitative } \\
\text { Environmental Costing Model for Flanders (tested on the } \\
\text { Nete sub-basin) }\end{array}$ \\
\hline & Studies & $\begin{array}{l}\text { Pilot projects on effectiveness of measures Scaldit project } \\
\text { (case study on nitrate reduction measures) } \\
\text { TWOL research project for inventory of environmental cost } \\
\text { efficiency of measures concerning diffuse pollution }\end{array}$ \\
\hline & Scale & Costs of measures assessed at the regional scale \\
\hline & Time & NA \\
\hline \multirow{4}{*}{ NL } & $\begin{array}{l}\text { Choice of } \\
\text { measures }\end{array}$ & $\begin{array}{l}\text { Expert judgement (processes and formats for data collection } \\
\text { on costs and effects of measures) } \\
\text { Regional water authorities developed } 5 \text { scenarios/measure } \\
\text { packages (measures already decided, basic measures, WFD } \\
\text { implementation with limited efforts/significant efforts/full } \\
\text { WFD implementation) }\end{array}$ \\
\hline & Guidance & Handbook for selection of cost-effective measures \\
\hline & Method & $\begin{array}{l}\text { No overall simulation program or hydroeconomic model to } \\
\text { support local level work for measure selection at catchment's } \\
\text { scale but tools have been developed (e.g. Explorer-model) }\end{array}$ \\
\hline & Studies & $\begin{array}{l}\text { Regional level: studies commissioned (consultants and } \\
\text { universities) to support selection of cost-effective measures }\end{array}$ \\
\hline
\end{tabular}


Table 1: $\quad$ Continued.

\begin{tabular}{|l|l|}
\hline & \multicolumn{1}{|c|}{ Selection of measures and CEA } \\
\hline Scale & $\begin{array}{l}\text { National level: discussions with specific sectors (contributions to } \\
\text { water problems and possible improvements - strategic analysis for } \\
\text { agriculture sector ; industrial sector: possibilities to take additional } \\
\text { measures: few options at national level, more potential at local level - } \\
\text { Source: Ecorys) }\end{array}$ \\
\hline Time & NA \\
\hline
\end{tabular}

Table 2: $\quad$ Information reported on cost-benefit analysis.

\begin{tabular}{|c|l|}
\hline & \multicolumn{1}{c|}{ CBA } \\
\hline FR & $\begin{array}{l}\text { Disproportionality threshold (if costs of supplementary measure are at least } \\
60 \% \text { higher than stakeholders' financial capacity, a CBA is required) } \\
\text { CBA undertaken at the WB scale } \\
\text { Benefits analysis: value transfer is mostly used and few benefits assessment } \\
\text { studies are undertaken } \\
\text { Different benefits evaluation methods are used in the various water agencies } \\
\text { Low acceptability of CBA from local stakeholders/policy makers (river } \\
\text { basin committees) } \\
\text { One study available for a sub-basin of Seine-Normandy on the cost of the } \\
\text { PoM and stakeholders capacity to pay }\end{array}$ \\
\hline BE & $\begin{array}{l}\text { CBA undertaken at the regional scale } \\
\text { Benefits assessed at the regional scale }\end{array}$ \\
\hline \multirow{5}{*}{ NL } & $\begin{array}{l}\text { Interdepartmental working group on CBA (discuss methods and progress, } \\
\text { reports to minister and Parliament) } \\
\text { 2005: CBA at national level: costs estimates (of current policies and } \\
\text { potential additional measures) } \\
\text { 2006: strategic CBA (5 scenarios with different levels of ambition) at } \\
\text { national level (potential intensities of different types of measures - water } \\
\text { quality, ecological, groundwater...). Rough benefits transfer study to assess } \\
\text { market and non-market benefits of WFD implementation. The decision } \\
\text { whether measures are part of list nº4 (still affordable) or 5 is based on } \\
\text { budgetary constraints at the regional level. } \\
\text { 2008: ex ante evaluation: one scenario selected for the draft RBMP ("the } \\
\text { priority package"). No monetary estimates of benefits: ecological benefits } \\
\text { presented as quality ratios in pictures (good ecological quality, poor } \\
\text { ecological quality, insufficient ecological quality, bad ecological quality). } \\
\text { Estimates of benefits will be used. There is a handbook to assess benefit } \\
\text { values developed at national level, using benefit transfer approaches }\end{array}$ \\
\hline
\end{tabular}

\section{Towards transaction cost optimisation strategies}

\subsection{Transaction characteristics of the social CBA}

To make a link between how tasks are performed and transaction costs, we rely on transaction characteristics having an impact on transaction costs. Transaction costs theory identifies three key transaction characteristics that are positively correlated with transaction costs: asset specificity, frequency and uncertainty. 
Table 3: Information reported on costs disproportion and exemptions.

\begin{tabular}{|c|l|}
\hline & \multicolumn{1}{|c|}{ Costs disproportion and justification of exemptions } \\
\hline FR & $\begin{array}{l}\text { Political objective following the Grenelle de l'Environnement: 2/3 of water } \\
\text { bodies need to reach the good status/potential by } 2015 . \\
\text { The threshold for disproportionate costs was defined by the ministry and } \\
\text { water agencies (if costs of supplementary measure are } 60 \% \text { higher than } \\
\text { stakeholders' financial capacity: a CBA is required). } \\
\text { Stakeholders' affordability: different assessments among water agencies } \\
\text { Effects of measures implementation on water price (water bill should not } \\
\text { exceed 3\% of household income) }\end{array}$ \\
\hline BE & $\begin{array}{l}\text { Disproportionality analysis for the entire POM is carried out at the scale of } \\
\text { the Flemish region } \\
\text { Affordability analysis undertaken and cost distribution on-going }\end{array}$ \\
\hline NL & $\begin{array}{l}\text { CBA based on both welfare economic and affordability arguments } \\
\text { Political character of disproportionate costs discussion is highlighted } \\
\text { (policy makers define what threshold should be used); several indicators } \\
\text { are suggested at different levels (i.e. costs as a \% of GDP, \% of increase of } \\
\text { the water bill compared to disposable household income...) } \\
\text { National accounting matrix including water accounts for river basins } \\
\text { (integrated RB accounting to support measurement of economic } \\
\text { significance of water uses) } \\
\text { No specific methodology/guidelines developed at national level (to assess } \\
\text { costs disproportion) }\end{array}$ \\
\hline
\end{tabular}

Table 4 gives an overview some of some specific transaction characteristics that impact positively or negatively on the transaction costs of performing the tasks under the WFD.

Once transaction characteristics and their most significant impacts on transaction costs are assessed, we can identify the likelihood of changing the factors generating transaction costs.

\subsection{Factors generating transaction costs}

Williamson [19, 20] proposed an analytical framework with four levels of social analysis. Each level requires a certain time to change: 100 to 1000 years for informal institutions (customs, traditions, norms, religion), 10 to 100 years for the institutional environment, 1 to 10 years for governance structures and resources allocation and employment are subject to continuous change.

The explaining factors of transaction characteristics can be categorised according to this classification.

\subsubsection{Culture}

Cultural aspects reflected by long-time/preferential partnerships, similar methodologies, guidelines or sources of information used, language or common approaches are the most anchored and would thus require a long time frame to evolve. This can be illustrated by French nationals working in Wallonia or same for Flemish and Dutch experts or consultants. 
Table 4: $\quad$ Transaction characteristics and effects on transaction costs.

\begin{tabular}{|c|c|c|}
\hline $\begin{array}{c}\text { Transaction } \\
\text { characteristics }\end{array}$ & $\begin{array}{c}\text { Related } \\
\text { transaction costs }\end{array}$ & Examples \\
\hline $\begin{array}{l}\text { Scale of analysis } \\
\text { Scale of action }\end{array}$ & $\begin{array}{l}\text { Monitoring costs } \\
\text { Coordination costs } \\
\text { Administration } \\
\text { costs }\end{array}$ & $\begin{array}{l}\text { CBA at a global scale or CBA at } \\
\text { small scale } \\
\text { Generate data at the right scale }\end{array}$ \\
\hline $\begin{array}{l}\text { Enabling } \\
\text { law/institutions }\end{array}$ & $\begin{array}{l}\text { Administration } \\
\text { costs }\end{array}$ & $\begin{array}{l}\text { Administrative procedures } \\
\text { required }\end{array}$ \\
\hline Uncertainty & $\begin{array}{l}\text { Coordination costs } \\
\text { Monitoring costs } \\
\text { Implementation } \\
\text { costs }\end{array}$ & $\begin{array}{l}\text { Water authorities' efforts to get } \\
\text { involved in the economic analysis } \\
\text { or reticence to act given } \\
\text { uncertainty of certain outcomes }\end{array}$ \\
\hline Experience & $\begin{array}{l}\text { Implementation } \\
\text { costs }\end{array}$ & $\begin{array}{l}\text { Data available, } \\
\text { competent/operational staff }\end{array}$ \\
\hline Information & $\begin{array}{l}\text { Research and } \\
\text { information (time, } \\
\text { effort, money) }\end{array}$ & Projects, studies undertaken \\
\hline $\begin{array}{l}\text { Methodology/ } \\
\text { methods used }\end{array}$ & Search costs & $\begin{array}{l}\text { Benefits estimation vs benefit } \\
\text { transfer }\end{array}$ \\
\hline Cooperation & $\begin{array}{l}\text { Implementation } \\
\text { costs } \\
\text { Coordination costs }\end{array}$ & Process facilitation \\
\hline $\begin{array}{l}\text { Human asset } \\
\text { specificity }\end{array}$ & $\begin{array}{l}\text { Implementation } \\
\text { costs }\end{array}$ & $\begin{array}{l}\text { Specialized staff hired (i.e. } \\
\text { economists) vs commissioning } \\
\text { studies }\end{array}$ \\
\hline $\begin{array}{l}\text { Frequency of } \\
\text { meetings }\end{array}$ & Coordination costs & $\begin{array}{l}\text { Internal meetings (water agency), } \\
\text { national (with other water } \\
\text { authorities, policy makers), } \\
\text { international (i.e. networks, } \\
\text { INBO, international commissions) }\end{array}$ \\
\hline
\end{tabular}

\section{Institutions}

Aspects related to the institutional environment (i.e. existing legalisation and how it integrates and operationalise principles such as integrated water management) would also take time to change. In France, a principle of the 1992 Water Legislation is "water pays for water", meaning that subsidies allocated for sanitation or pollution abatement project should be funded by water levies and taxes. This principle implies that costs' repercussions of the programs of measures need to be analyzed at the very local scale since local water users have to pay for it. Since the water body scale is too detailed to undertake cost-benefit analysis (i.e. the Rhine Meuse river basin has 644 water bodies), water agencies used stakeholders' capacity to pay as a first screening. For the water bodies remaining where the financial capacity is not sufficient, a CBA has to be carried 
out. This arrangement corresponds to a transaction cost optimisation strategy due to an institutional factor as it limits the number of CBAs necessary.

\subsubsection{Organisation}

Last, factors related to the governance structures or organisational arrangements are more responsive in terms of time. These aspects include possible changes regarding among other: role and competencies of personnel, data and knowledge management, scale of analysis and action, the methodology and methods used. An illustration is the need of specific economic know-how to implement the WFD and water agencies personnel (France, The Netherlands) is traditionally from an engineering background. As a response, some tasks can be internalised by water authorities (i.e. hiring economists in water agencies) while others can be delegated. These choices also correspond to transaction costs optimisation strategies. Pérard [21] has shown the role of transaction costs in water services outsourcing decisions.

Some limits to a static picture of transaction characteristics and effects on transaction costs include the dynamics of the process. The tasks described related to the economic analysis of the WFD are carried out in since about the year 2003 and should be finalized by December 2009. There also exist interactions between the effects of different characteristics. If an arrangement generates less transaction costs in a first instance, it could leave more transaction costs for the future. Also, exogenous factors such as the degree of previous EU policies implementation can impact transaction costs, for instance the size of the transaction (amount of basic measures). A major difficulty will lie in the organisation into a hierarchy of the transaction characteristics regarding their impact on transaction costs.

\section{Conclusion}

The WFD economic analysis is an ongoing process that will produce the final river basin management plans including the programs of measures and potential justification for economic exemptions by the end of 2009. For that reason, we suggest an approach to assess the implementation of the WFD economic analysis, by presenting the potential of a transaction cost framework that adds a governance dimension to economics. Transaction cost research is mostly based on empirical studies as it supposes the identification of practices in order to identify what the critical characteristics are. In the context of the WFD, this approach would allow to balance the costs of programs of measures with costs or constraints of the related process. It also allows pointing out which arrangements better optimise transaction costs or the arrangements inducing significant transaction costs. This leaves room for improvements and some key elements for policy changes lie in the factors affecting the transactions. Making a hierarchy of these factors based on transaction cost theory can help identifying priorities of action. To go further, a transaction cost quantitative assessment can support these findings. 


\section{Annex}

Table A1: Transaction costs typology.

\begin{tabular}{llll}
\hline Type of transaction cost & \multicolumn{3}{l}{ Incurred by } \\
\cline { 2 - 4 } & $\begin{array}{l}\text { Legislature/ } \\
\text { courts }\end{array}$ & Agencies & Stakeholders \\
\hline Research and information & + & ++ & + \\
Enactment or litigation & + & + & ++ \\
Design and implementation & & ++ & + \\
Support and administration & ++ & + \\
Contracting & + & ++ \\
Monitoring/detection & & ++ & + \\
Prosecution/enforcement & + & ++ & + \\
\hline ( ) Negligible transaction costs; $(+)$ low transaction costs; $(++)$ high \\
transaction costs.
\end{tabular}

Source: McCann et al [22].

\section{References}

[1] Dixit, A., The Making of Economic Policy: A Transaction-Cost Politics Approach, MIT Press, Cambridge, pp. 192, 1996

[2] Falconer, K. and Whitby, M., Transactions and administrative costs in countryside stewardship policies: an investigation for 8 European member states, Centre for Rural Economy (CRE), Department of Agricultural Economics and Food Marketing, University of Newcastle, pp.149, May 1999

[3] McCann, L. and Easter, K., Estimates of public sector transaction costs in NRCS programs, Journal of Agricultural and Applied Economics, 32(3), pp. $555-563,2000$

[4] McCann and Easter, K., Transaction costs of policies to reduce agricultural phosphorous pollution in the Minnesota River, Land Economics, 75(3), pp. 402-414, 1999

[5] Ducos, G., Efficacité et coûts de transaction des contrats agrienvironnementaux, $\mathrm{PhD}$ thesis, Université de Rennes 1, pp.168, 2007

[6] Beaud, M., Le coût social marginal des fonds publics, $\mathrm{PhD}$ thesis, Université de Franche-Comté, Besançon, pp. 249, 2000

[7] Jobin, D., A transaction cost-based approach to partnership performance evaluation, Evaluation, 14(4), pp. 437-465, 2008

[8] Arrow, K., The organization of economic activity: Issues pertinent to the choice of market versus nonmarket allocation, in The analysis and evaluation of public expenditure: The PPB system, Vol 1, US Joint Economic Committee, 91st Congress, U.S. Government Printing Office, pp. 48, 1969

[9] Ménard, C. and Saussier, S., Contractual choice and performance: the case of water supply in France, Revue d'économie industrielle, 92, pp. 385-404, 2000 
[10] Brouwer, R., The potential role of stated preference methods in the Water Framework Directive to assess disproportionate costs, Journal of Environmental Planning and Management, 51, pp. 597-614, 2008

[11] Kaika, M. and Page, B., The EU Water Framework Directive Part 1: European policy-making and the changing topography of lobbying. European Environment, 13(6), pp. 314-327, 2003

[12] Common Implementation Strategy for the WFD (2000/60/EC), Guidance Document $\mathrm{N}^{\circ} 1$, Economics and the Environment - The Implementation Challenge of the WFD, Produced by WG 2.6 - WATECO, pp. 274, 2003

[13] Crabbé, A. and Leroy, P., The handbook of policy evaluation, Earthscan, London, UK, p. 101, 2008

[14] Bouma, J.J. Personal communication, 24 April 2009, Chairman Erasmus Centre for Sustainability and Management, Erasmus University of Rotterdam

[15] Cemagref, Bilan des agences de l'eau en matière d'analyse économique, UMR G-Eau Cemagref, Montpellier, 2008

[16] Interwies, E. and Borowski, I., Current use of economic methods and models for the implementation of the WFD in selected EU-Member-States: the role of European research, InterSus, 2007, Berlin, Germany

[17] Nicolaï, S. Personal communication, 20 October 2008, Economist, RhineMeuse Water Agency, Moulins-Lès-Metz, France

[18] van der Veeren, R., Different cost-benefit analysis in the Netherlands for the European WFD, 4th EWA Brussels Conference "European Water Management and the Economic Aspects of the WFD", 4 November 2008,

[19] Williamson, O., The New Institutional Economics: Taking Stock, Looking Ahead, Journal of Economic Literature, 38, pp. 595-613, 2000

[20] Williamson, O., Transaction cost economics: How it works; where it is headed, De Economist, 146(1), pp. 23-55, 1998

[21] Pérard, E., Water policy: public or private? An approach based on cost of funds, transaction costs, efficiency and political costs, Policy and society, 27(4), pp. 193-219, 2008

[22] McCann, L., Colby, B., Easter, K., Kasterine, A., Kuperan K., Transaction cost measurement for evaluating environmental policies, Ecological Economics, 52(4), pp. 527-542, 2005 